\title{
International Evidence on the Determinants of Domestic Sovereign Debt Bank Holdings
}

\section{Dimitris K. Chronopoulos ${ }^{1}$ (D) $\cdot$ George Dotsis ${ }^{2} \cdot$ Nikolaos T. Milonas $^{2}$}

Received: 10 September 2018 / Revised: 8 August 2019 / Accepted: 2 September 2019/

Published online: 18 October 2019

(C) The Author(s) 2019

\begin{abstract}
In this paper, we examine the determinants of bank holdings of domestic sovereign debt with a panel dataset of 295 banks in 35 countries between 2002 and 2013. The findings indicate that the structure of bank ownership (domestic, foreign, or government ownership), the quality of governance, and the level of financial development of the countries in which banks operate all determine the level of home bias. Specifically, we find that domestic banks tend to hold more domestic sovereign debt relative to their foreign counterparts. We also provide evidence that home bias is even stronger when the domestic bank is controlled by its government. Moreover, home bias increases when government bonds are more risky, home governments are less effective, and when banking systems are less financially developed. Overall, we find that banks' home bias in holding sovereign debt is an international phenomenon that is determined by both bank- and country-specific factors.
\end{abstract}

Keywords Sovereign debt · Home bias · Moral suasion · Government ownership

JEL classification $\mathrm{G} 11 \cdot \mathrm{G} 21$

\section{Introduction}

The sovereign debt crisis erupted in Europe after the collapse of Lehman Brothers. This crisis has ignited research interest in the behavior of sovereign debt holders. A major concern during

Dimitris K. Chronopoulos

dc45@st-andrews.ac.uk

George Dotsis

gdotsis@econ.uoa.gr

Nikolaos T. Milonas

nmilonas@econ.uoa.gr

1 School of Management, University of St. Andrews, Gateway Building, Scotland KY16 9RJ, UK

2 Department of Economics, National and Kapodistrian University of Athens, Athens, Greece 
the Eurozone crisis was the negative feedback loop between the credit risk of sovereign debt and banks. Recent EU-wide stress tests have provided bank-level data for researchers to study sovereign debt holdings. ${ }^{1}$ The research has shown that European banks have a significant home bias in their holdings of sovereign bonds. In this paper we explore whether home bias applies only to European banks or is an international phenomenon despite the many legal, regulatory, ownership, and cultural differences that exist between banks as well as across countries. In particular, we seek to answer the following questions: Are banks owned by foreign entities less prone to home bias in their bond holdings? Does government ownership of banks affect the holdings of domestic sovereign debt? Do government-owned banks tend to buy more domestic sovereign bonds when credit conditions deteriorate? Does a country's level of financial system development, governance, and control over corruption affect the banks' holdings of domestic sovereign debt? Is the home bias in European banks a unique phenomenon or can we observe it internationally?

One of the reasons for the vicious circle between the credit risks of sovereign debt and banks in Eurozone countries is the large proportion of domestic sovereign debt that the banks hold. Sizable sovereign debt holdings can hurt capital adequacy and compromise banks' ability to efficiently allocate funds to worthwhile projects during a sovereign debt crisis. ${ }^{2}$ This inability could hinder economic activity when it is most needed, as was recently the case with Greece, Ireland, Portugal, and Spain.

There are various transmission channels through which the credit risk of domestic sovereign debt can affect banking stability. First, the deterioration in creditworthiness of domestic bonds damages the bank's balance sheet and capital adequacy by decreasing the value of assets. Second, the increased risk of sovereign debt reduces the value of the collateral that banks can use to raise funding from the interbank market or the central bank. Third, it has a negative impact on the funding costs of banks that benefit from either implicit or explicit government guarantees.

The interests of banks and the government are not necessarily contradictory, as they can extract mutual benefits from each other in the case of collusion. Collusion is more pronounced in the case of government-owned banks. Less pronounced collusion occurs between government-owned and private domestic banks, and no collusion exists between foreign banks and the home government. The degree of collusion can also be differentiated according to the institutional environment of the country in which banks operate. Significant collusion should not occur in countries with credible governments and considerable shareholder protection (Shleifer and Vishny 1997). In our empirical analysis, we investigate whether home bias and ownership structure are related, since governments can use moral suasion to ensure that banks, especially domestic banks, participate in new issues of sovereign bonds. In light of the above discussion, home bias should be even stronger in government-owned banks.

In terms of measuring the home bias in a bank's asset holdings, one proxy is the proportion of domestic sovereign bonds held in the bank's portfolio. Basic rules of diversification argue that bond holdings should be diversified across issuers and countries. However, the increased exposure of banks' to domestic sovereign bonds may happen for regulatory or risk-shifting reasons. For example, legislation in the European Union allows European banks to assign

\footnotetext{
${ }^{1}$ See Horváth et al. (2015) and De Marco and Macchiavelli (2016).

${ }^{2}$ Furthermore, a country's excessive sovereign debt may seriously hurt banks' ability to meet capital requirements in cases where the country is on the brink of bankruptcy. This was the case for Greek banks that lost more than 30 billion euros when the Private Sector Involvement program initiated in 2012 led to a haircut of 53.5\% of the face value of the Greek bonds held.
} 
zero-risk weights to the sovereign debt issued by any EU member country (see Kirschenmann et al. (2017) for the regulatory treatment of sovereign bond holdings in the EU). Therefore, holdings of domestic sovereign bonds may be more attractive for banks since they make capital requirements easier to meet. Another explanation of home bias in banks' assets is the risk-shifting hypothesis. This hypothesis argues that an increased exposure to domestic sovereign bonds may occur if equity holders wish to shift risk to bank creditors, since in the event of a sovereign default, a bank is likely to default anyway. Risk-shifting is more likely to be observed in less capitalized banks. ${ }^{3}$

A number of recent studies examine the determinants of domestic sovereign bond holdings in the context of the bank-sovereign nexus in the Eurozone by using bank-level data. Acharya et al. (2015) provide a theoretical model for the feedback loop between the credit risks of sovereign debt and banks. They use data on bank sovereign holdings from the Eurozone stress tests announced in 2010 to find a substantial home bias in banks' holdings of domestic sovereign bonds. Approximately $70 \%$ of these holdings were invested in domestic sovereign bonds. Ongena et al. (2018) use proprietary data on monthly security holdings of Eurozone based banks. They find that during the debt crisis of 2010-2012, domestic banks in stressed countries, especially government-owned or supported banks, increased their domestic sovereign bond holdings significantly more than their foreign counterparts. Horváth et al. (2015) use data on banks' holdings of sovereign debt from the EU-wide stress tests conducted annually during the years 2010-2013. Their empirical analysis shows that many European banks have a home bias and hold significant amounts of domestic sovereign debt. They find that home bias in banks is more significant if the government has positive ownership, sovereign debt is risky, and shareholder rights are strong. De Marco and Macchiavelli (2016) also use data from the EUwide stress tests and find that government-owned banks or those with politicians on the board of directors display greater home bias. Becker and Ivashina (2017) also find that government ownership and government influence through banks' boards of directors are positively related to Eurozone banks' bias for domestic sovereign debt. Kirschenmann et al. (2017) argue that a sovereign-bank feedback loop can also emerge in safe countries that belong to a group of financially integrated economies. They describe a subtle mechanism whereby banks in safe countries buy non-domestic sovereign bonds issued by riskier countries in the same group. In doing so, banks implicitly take on more credit risk without impairing their capital adequacy ratios. This is because regulatory rules allow banks to assign zero-risk weights to these purchases. The authors use data from Eurozone banks and, consistent with their hypothesis, find significant spillover effects from risky peripheral countries to safer core countries.

In this paper we examine the determinants of banks' domestic sovereign bond holdings using a unique dataset comprised of 295 banks in 35 countries between 2002 and 2013. We collect data on these holdings from a variety of sources, such as annual reports, websites, Bankscope, and EU-wide stress tests.

In contrast to previous studies that focus exclusively on post-2010 holdings data on Eurozone banks, our study is the first to investigate the determinants of banks' domestic sovereign bond holdings by using an extended sample of data from developing and developed economies that spans a relatively long time period. Our extended sample includes banks from countries with different levels of financial development and governance that allows us to more accurately pin down factors that determine both cross-country and cross-bank variations in domestic sovereign bond holdings.

\footnotetext{
${ }^{3}$ See, for example, Becker and Ivashina (2017).
} 
In particular, similar to other studies in the literature, we investigate whether banks' holdings of domestic sovereign bonds occur because of bank-specific factors, such as ownership structure (domestic, foreign, or state ownership). Another contribution is that the country's governance as well as the banking sector's development and capital market conditions are significant determinants of home bias in banks' bond holdings.

The empirical results of our study are as follows: Domestic banks tend to hold more domestic sovereign debt relative to their foreign counterparts. Moreover, we also find that home bias in sovereign debt holdings is more pronounced when the domestic bank is controlled by the government. The strength of this relationship, however, is moderated by the size of the financial sector. Our results regarding ownership structure and home bias are robust to alternative explanations, such as risk-shifting or regulatory standards. Regarding institutional and market factors, we find that home bias in sovereign bond holdings is higher in countries with less developed banking systems and less effective governance. Overall, home bias is an international phenomenon driven by both bank- and country-specific factors.

The remainder of the paper is structured as follows: In the next section, we postulate and discuss the main hypotheses tested in the empirical analysis. In Section 3, we describe the model used in our empirical analysis and provide a description of the various firm-specific and country-specific factors that can potentially affect the number of holdings of domestic sovereign debt. In Section 4, we discuss the empirical results, and Section 5 concludes.

\section{Research Hypotheses}

In the empirical analysis, we identify the effect of ownership structure, bank characteristics, and country characteristics on home bias. To this end, we measure banks' home bias using the ratio of domestic sovereign bonds relative to total assets. First, we examine the bias of foreign banks toward domestic bonds relative to their domestic counterparts, both government and privately owned.

\section{H1. Foreign banks hold less domestic sovereign debt relative to their domestic counterparts.}

According to our first hypothesis we expect foreign banks to hold fewer domestic sovereign bonds, because governments' moral suasion is more likely to be effective with respect to domestic banks (Reinhart and Sbrancia 2011). In this paper, we use the term moral suasion to describe a form of financial repression where the government forces banks to buy its bonds, even if the purchases are not an optimal decision from a portfolio allocation perspective. The moral suasion can entail explicit threats, such as stricter supervision or limited access to central bank funding, or implicit threats for unfavorable treatment in future allocations of government projects. Domestic banks, especially government-owned banks, can be more vulnerable to pressure from the government. This is an argument already advanced by Romans (1966).

\section{H2. Government-owned banks hold more domestic sovereign bonds relative to domestic privately owned banks.}

With the second hypothesis, we examine if the home bias in domestic banks is related to whether the bank is privately- or government-owned. Government-owned banks are more 
likely to hold more domestic sovereign debt relative to domestic privately owned banks because governments have greater sway over them. Apart from the moral suasion, the government can influence the composition of the bank's debt portfolio since, as the main equity holder, it can directly appoint high-level executives.

H3. Government-owned banks tend to buy more domestic sovereign bonds relative to domestic privately owned banks or foreign banks when credit conditions deteriorate.

This hypothesis predicts that when domestic sovereign bond yields increase, governmentowned banks purchase more of these bonds. This is because the government will first sway them to increase holdings of sovereign bonds when credit conditions deteriorate in order to roll-over existing bonds or issue new bonds to finance budget deficits. ${ }^{4}$ Broner et al. (2014) develop a model that rationalizes the increase in home bias during crisis periods. The authors argue that when the risk of sovereign default increases, there is discrimination in favor of domestic creditors, as they enjoy a higher expected return compared to foreign creditors. Discrimination arises because domestic creditors are more likely to be compensated in the event of default or because of regulatory bias and moral suasion.

\section{H4. The home bias in banks' balance sheets increases in countries that have less developed banking systems (H4a), less quality governance (H4b), and less control over corruption (H4c).}

Taken together, these hypotheses examine whether banks' home bias is related to the level of development of a country's banking system, its governance quality, and its control over corruption. We use the World Bank's Worldwide Governance Indicators to measure the quality of governance and control over corruption, whereas the banking system's level of development is captured by its structure and stability as well as its degree of competition. Here we hypothesize that the moral suasion channel is stronger in countries with less effective governance, low control over corruption and less developed banking systems. ${ }^{5}$ Our hypothesis is also motivated by studies that find that improved banking sector competition and better institutions have a positive impact on bank efficiency (see Brissimis et al., 2008; Hasan et al., 2009; Chronopoulos et al., 2013).

Home bias is not necessarily only caused by moral suasion. Inefficient asset allocation decisions due to home bias may also be caused by the regulatory preferential treatment of sovereign bonds or by the asymmetric payoff of equity (see Acharya and Steffen, 2015). Since sovereign debt issued by any EU member country has a zero-risk weight according to EU legislation, banks in Europe may prefer home sovereign bonds in order to comply more easily with capital requirements. Moreover, a bank may purchase more home bonds to shift the risk to its creditors (and to the central banks when bonds are used as collateral for repurchase agreements), and place a bet on its own survival, since in the event of a government default the bank is likely to fail anyway. This behavior is often called "risk-shifting" or "gambling for

\footnotetext{
${ }^{4}$ Asonuma et al. (2015) examine home bias using country aggregate data for the banking sector and find that home bias provides fiscal breathing space but also increases the riskiness of government debt because it delays fiscal consolidation.

${ }^{5}$ In the home bias literature, Gelos and Wie (2005) find that funds invest less in countries with low government and corporate transparency. Therefore, increased home bias in banks can also be attributed to the lack of demand for domestic bonds by foreign investors (non-banks).
} 
resurrection" (see Uhlig, 2013; Drechsler et al., 2016; Crosignani, 2015). In our empirical analysis we take into consideration these two alternative channels, which may be the cause of increased home bias in a bank's balance sheet. ${ }^{6}$

\section{Model Specification and Data}

\subsection{The Model}

The empirical model we use to study the relation between bank and country factors and the domestic sovereign debt holdings of banks is as follows:

$$
\pi_{i, s, t}=\pi_{i, s, t-1}+\sum_{j=1}^{J} b_{j} X_{i, s, t-1}^{J}+\sum_{m=1}^{M} b_{m} Y_{s, t-1}^{m}+v_{i}+\omega_{t}+\varepsilon_{i, s, t}
$$

where $\pi_{i, s, t}$ is the domestic sovereign debt held by bank $i$ in country $s$ as a proportion of its total assets at time $t$ with $i=1, \ldots, N ; t=1, \ldots, T ; s=1, \ldots, S$. Sovereign debt holdings are likely to show a tendency to persist over time that reflects a bank's decision to treat them as either held-to-maturity or available-for-sale investments. In order to account for this likelihood, we adopt a dynamic specification for the model by including a lagged dependent variable, the ratio of domestic sovereign debt to total assets, among the regressors. The dependent variable, $\pi_{i, s, t}$, is also regressed on bank-specific variables $X_{j}($ with $j=1, \ldots, J)$ observed at the bank-year level, and country characteristics $Y_{m}$ (with $m=1, \ldots, M$ ) observed at the country-year level. The model also includes time dummies, $\omega_{t}$, to capture time effects common to all banks as well as bank-specific fixed effects, $v_{i}$, to control for unobserved heterogeneity. $\varepsilon_{i, s, t}$ is a stochastic error term.

In our analysis, we fit Eq. (1) to the data by using the two-step system Generalised Method of Moments (GMM) with robust standard errors that are corrected with the method according to Windmeijer (2005). The system GMM reduces the potential biases in finite samples and the asymptotic imprecision associated with the difference estimator (Blundell and Bond 1998). We also use one-year lags of all independent variables to mitigate any other potential endogeneity concerns between the dependent variable and its determinant factors.

The consistency of the system GMM depends on both the validity of the assumption that the error term is not autocorrelated and on the validity of the instruments. Three specification tests are therefore reported. The first is a Hansen test of over-identifying restrictions that examines the validity of the instruments by analyzing the sample analogue of the moment conditions used in the estimation procedure. The other two tests examine the hypotheses of no first-order or second-order autocorrelation in the error term, respectively.

\footnotetext{
${ }^{6}$ Note that our empirical analysis does not allow us to distinguish empirically between moral suasion and "familiarity" driven by superior information acquisition by domestic investors (see Coval and Moskowitz, 1999; Van Nieuwerburgh and Veldkamp, 2009). This is in an interesting topic for future research.

${ }^{7}$ We measure banks' home bias using the ratio of domestic sovereign bonds relative to total assets. Studies that examine home bias in Eurozone banks also calculate home bias using a CAPM equilibrium approach. Home bias is measured as one minus the ratio of the share of a bank's sovereign debt portfolio allocated to foreign EU countries to the share of foreign EU country sovereign debt in all EU sovereign debt held by banks (see, e.g., De Marco and Macchiavelli 2016). We are not able to calculate this measure because typical balance sheets do not provide a detailed breakdown of a bank's government debt portfolio. A detailed breakdown of banks' government debt portfolios in the Eurozone was made publicly available for the purposes of the EU-wide stress tests.
} 


\subsection{Bank- and Country-Specific Factors}

Following Berger et al. (2005), we refer to the different types of bank ownership, namely, domestic, foreign, or government ownership, as forms of "governance". In order to control for the effect of a bank's governance on its domestic sovereign debt, we include the dummy variable Foreign bank that equals one if the ultimate owner is foreign, and zero otherwise; and the dummy variable Domestic bank that equals one if the ultimate owner is domestic and not the government, and zero otherwise. Information on foreign bank ownership is obtained from the database of Claessens and van Horen (2015), whereas information on government ownership is from the Bankscope database. Bankscope offers only a snapshot of ownership data for the most recent year. Therefore, we account for changes in the ownership structure for each bank over time using data from earlier editions of the Bankscope database that match the years considered in our study, as in Lensink et al. (2008). The variable for the log of total assets (Size) is used to control for the effect of the bank's size on its percentage of domestic sovereign debt. ${ }^{8}$ Moreover, we use the ratio of equity to assets $(E / T A)$ to control for a bank's leverage. The ratio of loans to total assets (Loans/Assets) represents the relative importance of lending to the bank's activity. Finally, we include the dummy variable $E U$ that equals one if a bank operates in a European Union member state, and zero otherwise.

The country-specific characteristics include a wide set of structural, institutional, and macroeconomic variables. First, we use the yield of a government bond with a 10 -year maturity (Sovereign debt yield) that comes from Datastream as a proxy for the riskiness of the domestic sovereign bonds held by banks. In addition, we include the debt to GDP ratio (Debt/GDP) to capture the condition of each country's public finances. This variable is drawn from the IMF's IFS database. GDP growth comes from the World Development Indicators and measures the economic growth of a country. We also use indices regarding the characteristics of the countries' financial system from the Global Financial Development Database provided by the World Bank (see Čihák et al. 2012). From this database we use Market concentration that we define as the percentage of total assets held by the five largest banks in the market as a summary measure of the industry's structure. The Boone indicator and the Z-score are also included in the regression to control for the degree of competition and the stability of the banking system, respectively. The Boone indicator is calculated as the elasticity of profits to marginal costs. As the Boone indicator becomes more negative, it indicates increased competition in the banking sector. Similarly, the Z-score is calculated at the banking sector level as a weighted average of all banks' distance to default; hence, a high Z-score indicates a low probability of insolvency among entities in the banking sector.

We also control for institutional differences across countries using two indicators drawn from the World Bank's Worldwide Governance Indicators as documented in Kaufmann et al. (2009). These indicators capture different aspects of a country's governance framework, namely (i) Government Effectiveness, and (ii) Control over Corruption. Government Effectiveness is an index that captures perceptions of the quality of public services and the quality of the civil service and its degree of independence from political pressures. Further, it captures the quality of the formulation and implementation of policy, and the credibility of the government's commitment to such policies. On the other hand, Control over Corruption is an index that captures perceptions of the extent to which public power is exercised for private gain as

\footnotetext{
${ }^{8}$ We use the prevailing end of year foreign exchange rate as sourced from Bankscope to express banks' total assets in millions of US dollars.
} 
well as the degree to which elites and private interests influence the government. The values that both Government Effectiveness and Control over Corruption can take on by construction range between -2.5 and 2.5. Table 1 provides definitions and data sources for the bank- and country-specific variables used for estimating Eq. (1).

\subsection{Descriptive Statistics}

Our analysis is based on data from 295 banks in 35 countries between 2002 and 2013. Our sample is primarily driven by the availability of data on bank holdings of domestic debt issued by central or local governments. These data are collected from the Bankscope database (using the raw data model of Fitch-Ratings), annual reports, company websites, and EU-wide stress tests conducted in 2010, 2011, 2012, and 2013. ${ }^{9}$ However, a number of countries (including Argentina, China, Mexico and the US) do not have available data on domestic sovereign debt holdings (either because they are reported combined with debt issued by domestic government-sponsored corporations or with debt issued by foreign governments) and are excluded from the sample. This exclusion somewhat limits our ability to generalize our findings. The distribution of banks across the countries included in the sample is depicted in Table 2, whereas Table 3 reports the summary statistics of the variables in the empirical analysis.

The average ratio of domestic sovereign debt to total assets is $12.1 \%$. Regarding ownership structure, $27.2 \%$ of the banks are classified as foreign-owned, $18.9 \%$ as government-owned, and $53.7 \%$ as domestic. Institutional quality factors are in the range of 0.7 to 0.9 , and the average 10 -year bond yield is $5.0 \%$. The average equity to total assets is $8.3 \%$, and the average loans to total assets is $56.4 \%$. Average GDP growth is $3.2 \%$, and the average debt to GDP ratio is around $75 \%$.

\section{Empirical Results}

\subsection{Baseline Regression}

This section presents the results of our main empirical analysis. We regress banks' domestic government debt holdings scaled by their total assets on one-period lagged values of that ratio; a set of bank governance indicators; and a set of bank, industry, and macroeconomic covariates.

Table 4 presents results from the estimation of Eq. (1) with alternative estimators. In columns 1 and 2, we present the estimates of Eq. (1) (excluding market and country institutional variables) with a pooled OLS and fixed effects estimators, respectively. Bond (2002) argues that in dynamic relationships these estimators are both biased and inconsistent. Furthermore, Baltagi (2008) find that a pooled OLS produces upward biased estimates of the coefficient for the lagged dependent variable, while Nickell (1981) shows that a fixed effects estimator is downward biased (Nickell, 1981). However, their use provides us with an interval

\footnotetext{
${ }^{9}$ Bankscope contains data on balance sheets and income statements as generated by local accounting practices for a large number of banks worldwide. One of the attractive features of Bankscope is that it provides that information in a format that can be comparable across different countries. Nevertheless, for the purpose of our study, we use the information generated by local accounting practices. Specifically, we draw information on banks' domestic sovereign bond holdings for those countries where data is available due to their local accounting practices. For the construction of our dependent variable, we only use information on domestic sovereign bonds issued by the central and local governments of each country.
} 
Table 1 Variable definitions and data sources

\begin{tabular}{|c|c|c|}
\hline Name & Description & Data source \\
\hline \multicolumn{3}{|l|}{ Dependent variable } \\
\hline $\begin{array}{l}\text { Domestic } \\
\text { Sovereign Debt } \\
\text { (Home bias) }\end{array}$ & $\begin{array}{l}\text { Domestic sovereign debt holdings to } \\
\text { total assets }\end{array}$ & $\begin{array}{l}\text { Bankscope, annual reports, } \\
\text { companies' websites, } \\
\text { EU-wide stress tests con- } \\
\text { ducted in } 2010,2011 \text {, } \\
2012 \text { and } 2013\end{array}$ \\
\hline \multicolumn{3}{|l|}{ Bank characteristics } \\
\hline Size & $\begin{array}{l}\text { Log of total assets in millions of US } \\
\text { dollars }\end{array}$ & Bankscope \\
\hline $\mathrm{E} / \mathrm{TA}$ & Equity over total assets & Bankscope \\
\hline Loans/Assets & Loans over total assets & Bankscope \\
\hline \multicolumn{3}{|c|}{ Main explanatory variables } \\
\hline Foreign Bank & $\begin{array}{l}\text { Dummy variable that equals one if a } \\
\text { bank's ultimate owner is foreign, } \\
\text { and zero otherwise. }\end{array}$ & $\begin{array}{l}\text { Claessens and van Horen } \\
\text { (2015) }\end{array}$ \\
\hline Domestic Bank & $\begin{array}{l}\text { Dummy variable that equals one if a } \\
\text { bank's ultimate owner is private and } \\
\text { domestic, and zero otherwise. }\end{array}$ & Bankscope \\
\hline $\begin{array}{l}\text { Sovereign debt } \\
\text { yields }\end{array}$ & 10 -year government bond yield & Datastream \\
\hline Debt/GDP & $\begin{array}{l}\text { General government gross debt as a } \\
\text { percentage of GDP }\end{array}$ & IMF \\
\hline GDP growth & GDP growth & $\begin{array}{l}\text { World Development } \\
\text { Indicators }\end{array}$ \\
\hline $\begin{array}{l}\text { Market } \\
\text { concentration }\end{array}$ & $\begin{array}{l}\text { Percentage of total assets held by the } \\
\text { five largest banks in the market. }\end{array}$ & $\begin{array}{l}\text { Global Financial } \\
\text { Development Indicators }\end{array}$ \\
\hline Boone indicator & $\begin{array}{l}\text { A measure of degree of competition, } \\
\text { calculated as the elasticity of profits } \\
\text { to marginal costs }\end{array}$ & $\begin{array}{l}\text { Global Financial } \\
\text { Development Indicators }\end{array}$ \\
\hline Z-score & $\begin{array}{l}\text { A measure of the stability of the } \\
\text { banking system that is defined as } \\
\text { ROA+(equity/assets) }) / \mathrm{sd}(\mathrm{ROA})\end{array}$ & $\begin{array}{l}\text { Global Financial } \\
\text { Development Indicators }\end{array}$ \\
\hline $\begin{array}{l}\text { Government } \\
\text { effectiveness }\end{array}$ & $\begin{array}{l}\text { An index capturing perceptions of the } \\
\text { quality of public services, the } \\
\text { quality of the civil service, and the } \\
\text { degree of its independence from } \\
\text { political pressure; the quality of } \\
\text { policy formulation and } \\
\text { implementation; and the credibility } \\
\text { of the government's commitment to } \\
\text { such policies }\end{array}$ & $\begin{array}{l}\text { Worldwide Governance } \\
\text { Indicators }\end{array}$ \\
\hline $\begin{array}{l}\text { Control over } \\
\text { corruption }\end{array}$ & $\begin{array}{l}\text { An index capturing perceptions of the } \\
\text { extent to which public power is } \\
\text { exercised for private gain that } \\
\text { includes both petty and large-scale } \\
\text { forms of corruption as well as } \\
\text { "capture" of the state by elites and } \\
\text { private interests }\end{array}$ & $\begin{array}{l}\text { Worldwide Governance } \\
\text { Indicators }\end{array}$ \\
\hline EU & $\begin{array}{l}\text { Dummy variable that equals one if the } \\
\text { bank operates in a European Union } \\
\text { member state, and zero otherwise }\end{array}$ & Bankscope \\
\hline
\end{tabular}

of values within which the true parameter of the lagged dependent variable lies. As such, these estimates serve to check on the consistency of the system GMM, our preferred estimator in this setting (Bond, 2002). Column 3 shows that the estimate of the coefficient for the lagged 
Table 2 This table presents the distribution of banks across the countries included in the sample

\begin{tabular}{lrlr}
\hline Country & Number of banks & Country & Number of banks \\
\hline Australia & 4 & Latvia & 7 \\
Austria & 3 & Lithuania & 3 \\
Belgium & 6 & Luxembourg & 6 \\
Brazil & 5 & Malta & 5 \\
Bulgaria & 3 & Netherlands & 9 \\
Canada & 37 & New Zealand & 1 \\
Croatia & 11 & Norway & 1 \\
Cyprus & 3 & Poland & 1 \\
Czech Republic & 3 & Portugal & 6 \\
Denmark & 4 & Russia & 9 \\
France & 2 & Singapore & 3 \\
Germany & 13 & Slovakia & 5 \\
Greece & 3 & Slovenia & 5 \\
Hungary & 7 & South Africa & 2 \\
India & 67 & Spain & 9 \\
Ireland & 3 & Sweden & 6 \\
Italy & 9 & United Kingdom & 14 \\
Japan & 20 & & \\
\hline
\end{tabular}

dependent variable using system GMM lies in the interval $(0.322,0.804)$ provided by the OLS and fixed effects estimates, and its magnitude (0.748) indicates that banks' domestic sovereign debt holdings are quite persistent. Moreover, the consistency of the system GMM is further confirmed by the Hansen test that shows no evidence of over-identifying restrictions, and the AR2 test that indicates there is no second-order autocorrelation.

Several conclusions arise from the results in column 3. The parameter estimate of the variable Foreign bank indicates that foreign banks hold $2.2 \%$ less domestic sovereign debt relative to their domestic counterparts. This finding is in line with hypothesis $\mathrm{H} 1$. The size of the bank is negatively related to the domestic sovereign bond holdings; small banks are more prone

Table 3 This table presents summary statistics for the variables used in the empirical analysis. The variables are defined in Table 1

\begin{tabular}{llrrrrr}
\hline Variable & Level & Mean & Median & Std. Dev. & Obs. & No. of Countries \\
\hline Dependent variable & & & & & & \\
$\quad$ Domestic Sovereign Debt & Bank & 0.121 & 0.076 & 0.129 & 1740 & 35 \\
Bank characteristics & & & & & & \\
$\quad$ Size & Bank & 16.472 & 16.231 & 2.504 & 1740 & 35 \\
E/TA & Bank & 0.083 & 0.065 & 0.083 & 1740 & 35 \\
Loans/Assets & Bank & 0.564 & 0.589 & 0.191 & 1727 & 35 \\
Main explanatory variables & & & & & & \\
Foreign bank & Bank & 0.272 & 0.000 & 0.445 & 1740 & 35 \\
$\quad$ Government-owned bank & Bank & 0.189 & 0.000 & 0.391 & 1740 & 35 \\
Domestic bank & Bank & 0.537 & 1.000 & 0.498 & 1740 & 35 \\
Sovereign debt yield & Country & 5.033 & 4.661 & 2.415 & 1653 & 35 \\
Debt/GDP & Country & 74.762 & 71.608 & 48.435 & 1693 & 35 \\
GDP growth & Country & 3.222 & 2.949 & 4.274 & 1733 & 35 \\
Market concentration & Country & 59.780 & 64.572 & 27.413 & 1707 & 35 \\
Boone indicator & Country & -0.057 & -0.050 & 0.083 & 1729 & 35 \\
Z-score & Country & 21.529 & 23.270 & 11.695 & 1740 & 35 \\
Government effectiveness & Country & 0.829 & 0.960 & 0.825 & 1740 & 35 \\
Control over corruption & Country & 0.722 & 0.810 & 1.020 & 1740 & 35 \\
\hline
\end{tabular}


to home bias. The estimated coefficient for the bank size variable captures the semi-elasticity of domestic sovereign bond holdings with respect to the log bank size. According to this estimate a $1 \%$ increase in asset size decreases domestic sovereign bond holdings by 0.3 percentage points. Bank leverage is not statistically and significantly related to domestic sovereign bond holdings. According to the data, highly leveraged banks do not tend to hold more domestic sovereign debt, so the risk-shifting hypothesis is probably not a sufficient explanation for the observed home bias in domestic sovereign bond holdings.

The loan to assets ratio is negatively related to domestic sovereign bond holdings and is statistically significant at the 5\% level. A plausible interpretation of this result is that increased home bias in domestic sovereign bond holdings is associated with "crowding out" and reduced financing in the private sector. Banks that hold significant amounts of domestic sovereign debt may have fewer funds available for the private sector. Becker and Ivashina (2017) also find that home bias in the Eurozone has led to a significant crowding out of corporate lending.

The statistically significant parameter estimate on sovereign bond yields indicates that home bias increases, and banks tend to hold more sovereign debt when sovereign bonds become riskier. This is consistent with our hypothesis that moral suasion and pressure on banks

Table 4 The dependent variable is the ratio of domestic sovereign debt holdings to total assets to measure the role of foreign ownership. The covariates are defined in Table 1. We estimate Models (1) and (2) using pooled OLS and fixed effects estimators, respectively, with standard errors clustered at the bank level. Model (3) is estimated using the two-step system GMM. Windmeijer (2005) corrected standard errors are given in parentheses for this model. AR1 and AR2 are the $p$ values of the tests for first- and second-order autocorrelation, respectively. Hansen is the $\mathrm{p}$ value of the Hansen test of over-identifying restrictions

\begin{tabular}{|c|c|c|c|}
\hline & $\begin{array}{l}\text { OLS } \\
(1)\end{array}$ & $\begin{array}{l}\mathrm{FE} \\
(2)\end{array}$ & $\begin{array}{l}\text { Sys-GMM } \\
\text { (3) }\end{array}$ \\
\hline Domestic Sovereign Debt ${ }_{t-1}$ & $\begin{array}{l}0.804 * * * \\
(0.027)\end{array}$ & $\begin{array}{l}0.322 * * * \\
(0.079)\end{array}$ & $\begin{array}{l}0.748 * * * \\
(0.048)\end{array}$ \\
\hline Foreign bank & $\begin{array}{l}-0.0032 * * \\
(0.0015)\end{array}$ & $\begin{array}{l}-0.008^{*} \\
(0.004)\end{array}$ & $\begin{array}{l}-0.022 * * \\
(0.009)\end{array}$ \\
\hline Size & $\begin{array}{l}-0.002 * * * \\
(0.0009)\end{array}$ & $\begin{array}{l}-0.025 * \\
(0.012)\end{array}$ & $\begin{array}{l}-0.003 * * * \\
(0.001)\end{array}$ \\
\hline $\mathrm{E} / \mathrm{TA}$ & $\begin{array}{l}-0.024 \\
(0.053)\end{array}$ & $\begin{array}{l}-0.089 \\
(0.099)\end{array}$ & $\begin{array}{l}-0.052 \\
(0.066)\end{array}$ \\
\hline Loans/Assets & $\begin{array}{l}-0.021^{*} \\
(0.011)\end{array}$ & $\begin{array}{l}-0.037 \\
(0.027)\end{array}$ & $\begin{array}{l}-0.037 * * \\
(0.018)\end{array}$ \\
\hline Sovereign debt yield & $\begin{array}{l}0.010 * * * \\
(0.002)\end{array}$ & $\begin{array}{l}0.002 \\
(0.002)\end{array}$ & $\begin{array}{l}0.015 * * * \\
(0.003)\end{array}$ \\
\hline$\left(\right.$ Sovereign debt yield) ${ }^{2}$ & $\begin{array}{l}-0.0005 * * * \\
(0.0001)\end{array}$ & $\begin{array}{l}-0.0001 \\
(0.0001)\end{array}$ & $\begin{array}{l}-0.0008 * * * \\
(0.0002)\end{array}$ \\
\hline (Debt/GDP) & $\begin{array}{l}0.0003 * * * \\
(0.00005)\end{array}$ & $\begin{array}{l}0.0004 \\
(0.0002)\end{array}$ & $\begin{array}{l}0.0004 * * * \\
(0.00008)\end{array}$ \\
\hline GDP growth & $\begin{array}{l}0.001 * * \\
(0.0005)\end{array}$ & $\begin{array}{l}-0.002 \\
(0.001)\end{array}$ & $\begin{array}{l}0.0009 \\
(0.0007)\end{array}$ \\
\hline EU & $\begin{array}{l}0.007 \\
(0.004)\end{array}$ & $\begin{array}{l}0.085 \\
(0.063)\end{array}$ & $\begin{array}{l}0.007 \\
(0.004)\end{array}$ \\
\hline Year fixed effects & YES & YES & YES \\
\hline Number of Observations & 1217 & 1217 & 1217 \\
\hline Number of Banks & 295 & 295 & 295 \\
\hline AR1 & & & 0.000 \\
\hline AR2 & & & 0.751 \\
\hline Hansen & & & 0.920 \\
\hline
\end{tabular}

$*, * *$, and $* * *$ denote significance at the $10 \%, 5 \%$, and $1 \%$ levels, respectively 
to participate in new issues of sovereign bonds becomes more intense when conditions deteriorate in the bond market, and governments find it difficult to attract funding from foreign investors. However, the negative sign on the squared bond yields shows that the relationship is concave, and domestic sovereign bond holdings increase at a declining rate as conditions deteriorate in the government bond market.

Domestic sovereign bond holdings are also positively related to the Debt/GDP ratio. In other words, banks in highly indebted countries tend to hold more domestic sovereign bonds. This result is consistent with the observed bank-sovereign nexus phenomenon, where a negative economic outlook in highly indebted countries and a drop in government bond values can cause significant losses in bank holdings and trigger a negative feedback loop between the credit risks of sovereign debt and banks. The coefficient for $E U$ is insignificant in all specifications under consideration. We interpret this result as evidence that European banks do not hold significantly more domestic sovereign bonds due to the preferential treatment of sovereign debt in the EU as compared to banks in other countries.

In column 1 of Table 5, we repeat the previous analysis by further separating domestic banks into government-owned and privately owned banks and by relying on the system GMM. To this end, we augment Eq. (1) with Domestic bank. ${ }^{10}$ We find that home bias is more prevalent in government-owned banks relative to privately owned banks, but even more so compared to foreign banks. Specifically, domestic privately owned banks hold $2.8 \%$ less domestic sovereign bonds relative to government-owned banks (the coefficient for Domestic bank is -0.028), whereas the difference jumps to $4.6 \%$ when comparing foreign banks with government-owned banks (the coefficient for Foreign bank is -0.046). This finding is consistent with hypothesis $\mathrm{H} 2$ regarding the impact of ownership structure and the effect of moral suasion on domestic sovereign bond holdings. The size and significance of the coefficients with respect to the other explanatory variables are largely in line with those reported in column 3 of Table 4.

We also investigate whether the different types of ownership structure can affect banks' domestic sovereign bond holdings differently for different levels of a country's risk. To this end, column 2 of Table 5 presents the estimates of a model specification that takes into consideration the interaction between ownership structure and sovereign risk. Both interactive terms between Sovereign bond yields and Domestic bank and Foreign bank have negative and statistically significant coefficients at the $5 \%$ and $10 \%$ level, respectively. These results show that both privately owned domestic banks and foreign banks decrease, on average, their domestic sovereign bond holdings when their yields increase, which confirms hypothesis $\mathrm{H} 3$.

Columns 3 to 5 of Table 5, respectively, test our hypotheses $\mathrm{H} 4 \mathrm{a}-\mathrm{H} 4 \mathrm{c}$ by introducing banking sector and country institutional variables into the analysis. Indeed, the effect of ownership remains robust in these specifications. The positive coefficient for the Z-score indicates that holdings of domestic sovereign debt are higher when the banking system is more stable, while home bias decreases as competition in the market increases (Boone indicator). Taken together, these findings lend partial support to hypothesis H4a, that home bias in banks' balance sheets increases in countries that have less developed banking systems. On the other hand, domestic sovereign bond holdings are negatively related to levels of both government effectiveness (column 4) and control over corruption (column 5). These findings, respectively, are in line with our hypotheses $\mathrm{H} 4 \mathrm{~b}$ and $\mathrm{H} 4 \mathrm{c}$. That is, banks that operate in countries whose institutional

\footnotetext{
${ }^{10}$ We omit the dummy variable that identifies government-owned banks from our analysis in order to avoid the dummy variable trap. In doing so, government-owned banks become the reference category for our analysis.
} 
Table 5 The dependent variable is the ratio of domestic sovereign debt holdings to total assets to measure the role of state ownership. The covariates are defined in Table 1. We estimate all regressions using the two-step system GMM. Windmeijer (2005) corrected standard errors are in the parentheses. AR1 and AR2 are the p values of the tests for first- and second-order autocorrelation, respectively. Hansen is the $p$ value of the Hansen test of over-identifying restrictions

\begin{tabular}{|c|c|c|c|c|c|}
\hline & Sys-GMM & Sys-GMM & Sys-GMM & Sys-GMM & Sys-GMM \\
\hline & (1) & (2) & (3) & (4) & $(5)$ \\
\hline \multirow[t]{2}{*}{ Domestic Sovereign Debt ${ }_{t-1}$} & $0.712^{* * *}$ & $0.708 * * *$ & $0.714^{* * * *}$ & $0.688^{* * *}$ & $0.690 * * *$ \\
\hline & $(0.054)$ & $(0.053)$ & $(0.054)$ & $(0.061)$ & $(0.057)$ \\
\hline \multirow[t]{2}{*}{ Domestic bank } & $-0.028 * *$ & $-0.019 *$ & $-0.021 *$ & $-0.023 *$ & $-0.023 *$ \\
\hline & $(0.013)$ & $(0.010)$ & $(0.012)$ & $(0.012)$ & $(0.013)$ \\
\hline \multirow[t]{2}{*}{ Domestic bank $*$ Sovereign debt yield } & & $-0.009^{* *}$ & & & \\
\hline & & $(0.004)$ & & & \\
\hline \multirow[t]{2}{*}{ Foreign bank } & $-0.046^{* * *}$ & $-0.031 * *$ & $-0.037 * *$ & $-0.039 * *$ & $-0.039 * *$ \\
\hline & $(0.017)$ & $(0.015)$ & $(0.015)$ & $(0.015)$ & $(0.015)$ \\
\hline \multirow[t]{2}{*}{ Foreign bank $*$ Sovereign debt yield } & & $-0.008 *$ & & & \\
\hline & & $(0.005)$ & & & \\
\hline \multirow[t]{2}{*}{ Size } & $-0.004 * * *$ & $-0.004 * * *$ & $-0.004 * * *$ & $-0.004 * * *$ & $-0.004 * * *$ \\
\hline & $(0.001)$ & $(0.001)$ & $(0.001)$ & $(0.001)$ & $(0.001)$ \\
\hline \multirow[t]{2}{*}{$\mathrm{E} / \mathrm{TA}$} & -0.021 & -0.018 & -0.023 & -0.021 & -0.022 \\
\hline & $(0.073)$ & $(0.071)$ & $(0.070)$ & $(0.080)$ & $(0.073)$ \\
\hline \multirow[t]{2}{*}{ Loans/Assets } & $-0.039 *$ & -0.030 & -0.030 & -0.035 & -0.037 \\
\hline & $(0.021)$ & $(0.022)$ & $(0.021)$ & $(0.023)$ & $(0.023)$ \\
\hline \multirow[t]{2}{*}{ Sovereign debt yield } & $0.014^{* * * *}$ & $0.021 * * *$ & $0.014 * * *$ & $0.011 * * *$ & $0.012 * * *$ \\
\hline & $(0.003)$ & $(0.004)$ & $(0.003)$ & $(0.004)$ & $(0.003)$ \\
\hline \multirow[t]{2}{*}{$\left(\right.$ Sovereign debt yield) ${ }^{2}$} & $-0.0007 * * *$ & $-0.0005^{* *}$ & $-0.0006^{* * * *}$ & $-0.0005 * * *$ & $-0.0006^{* *}$ \\
\hline & $(0.0002)$ & $(0.0002)$ & $(0.0002)$ & $(0.0002)$ & $(0.0002)$ \\
\hline \multirow[t]{2}{*}{ Debt/GDP } & $0.0004 * * *$ & $0.0003 * * *$ & $0.0004 * * *$ & $0.0003 * * *$ & $0.0004 * * *$ \\
\hline & $(0.0001)$ & $(0.00009)$ & $(0.00009)$ & $(0.00006)$ & $(0.00009)$ \\
\hline \multirow[t]{2}{*}{ GDP growth } & 0.0009 & 0.0006 & 0.0009 & 0.0005 & 0.0007 \\
\hline & $(0.0007)$ & $(0.0007)$ & $(0.0006)$ & $(0.0006)$ & $(0.0006)$ \\
\hline \multirow[t]{2}{*}{ Z-score } & & $0.0004 *$ & $0.0004^{*}$ & $0.0005^{*}$ & $0.0005^{*}$ \\
\hline & & $(0.0002)$ & $(0.0002)$ & $(0.0002)$ & $(0.0002)$ \\
\hline \multirow[t]{2}{*}{ Market concentration } & & 0.0001 & 0.0001 & 0.00017 & 0.0001 \\
\hline & & $(0.0001)$ & $(0.0001)$ & $(0.0001)$ & $(0.0001)$ \\
\hline \multirow[t]{2}{*}{ Boone indicator } & & $0.045 * *$ & $0.043 * *$ & 0.027 & $0.033^{*}$ \\
\hline & & $(0.020)$ & $(0.018)$ & $(0.017)$ & $(0.019)$ \\
\hline \multirow[t]{2}{*}{ Government effectiveness } & & & & $-0.008^{*}$ & \\
\hline & & & & $(0.004)$ & \\
\hline \multirow[t]{2}{*}{ Control over corruption } & & & & & $-0.005^{*}$ \\
\hline & & & & & $(0.002)$ \\
\hline \multirow[t]{2}{*}{ EU } & 0.007 & 0.007 & 0.006 & 0.007 & 0.005 \\
\hline & $(0.004)$ & $(0.005)$ & $(0.004)$ & $(0.005)$ & $(0.004)$ \\
\hline Year fixed effects & YES & YES & YES & YES & YES \\
\hline Number of Observations & 1217 & 1208 & 1208 & 1208 & 1208 \\
\hline Number of Banks & 295 & 293 & 293 & 293 & 293 \\
\hline AR1 & 0.000 & 0.000 & 0.000 & 0.000 & 0.000 \\
\hline AR2 & 0.831 & 0.932 & 0.805 & 0.766 & 0.784 \\
\hline Hansen & 0.933 & 0.626 & 0.835 & 0.911 & 0.949 \\
\hline
\end{tabular}

$*, * *$, and $* * *$ denote significance at the $10 \%, 5 \%$, and $1 \%$ levels, respectively

qualities (represented by Control over Corruption and Government Effectiveness) are weak are more likely to hold domestic sovereign bonds on their balance sheets. This is consistent with the view that governments can exert moral suasion and influence over banks in countries where the degree of independence from political pressure is low. 


\subsection{Sensitivity Checks}

In this subsection, we investigate the sensitivity of our inferences to sample selectivity, the definition of the dependent variable, and the choice of the estimation method. The sensitivity checks are reported in Tables 6 and 7.

There is substantial evidence that EU banks differentiate their sovereign bond portfolios based on ownership structure. We therefore examine the impact of sample selectivity on our inferences, and especially the possibility that our results are driven by the behavior of EU banks. To account for this possibility, we reestimate our canonical model after adding an interaction term between the different types of bank ownership and $E U$. The results are presented in column 1 of Table 6 . The coefficients for the interaction terms of interest are statistically insignificant and indicate that, on average, EU and non-EU foreign and domestic privately owned banks behave similarly in terms of domestic sovereign bond holdings.

In the same spirit, we also examine whether foreign banks from neighboring countries might have similar investment patterns to domestic banks in the host country. To this end, we augment Eq. (1) with Contiguous that equals one if the foreign bank is located in a contiguous neighboring country and has a controlling share, and zero otherwise. We also add its interaction with Foreign bank. ${ }^{11}$ If there are spillover effects in banks' investment patterns across neighboring countries, we should find a statistically significant coefficient for the interaction term. Column 2 of Table 6 presents the results of this analysis. The coefficient of interest is statistically insignificant that indicates the distance between home and host countries plays no role in the investment patterns of foreign banks.

To provide additional insights, we also examine whether countries with enlarged banking sectors relative to their economies could be driving our results. That is, in countries that perform "special roles" in the global financial system (e.g., Cyprus, Malta, and Luxembourg, among others) the home bias might be less prevalent. To this end, we reestimate Eq. (1) by adding Financial sector size that is defined as the ratio of the financial intermediaries' assets to gross domestic product, and its interaction with both Domestic bank and Foreign bank. ${ }^{12,13}$ The results are presented in column 3 of Table 6 . Both interaction terms have a negative coefficient, but only Domestic bank * Financial sector size is statistically significant. This result means that the relative size of the financial sector plays a moderating role in the home bias of domestic banks. A plausible explanation for this finding is that moral suasion weakens in countries with enlarged financial sectors that possibly act as financial centers and aim to attract funds from foreign investors.

To further investigate the sensitivity of our results to sample selectivity, we examine the distribution of banks across countries. To ensure that the results are not biased by the overrepresentation of some countries in our sample, we reestimate Eq. (1) by weighting the observations by the inverse of the number of observations for each country. The results, which are presented in column 4 of Table 6 , are consistent with our main findings.

Next, to avoid outliers driving our inferences, we winsorize the dependent variable at the 1st and 99th percentiles of its empirical distribution. The results, reported in column 1 of

\footnotetext{
${ }^{11}$ The results are also robust to the use of the geodesic distance between the capital cities of the host and home countries of foreign banks.

${ }^{12}$ The data are obtained from the Financial Structure Database available from the World Bank.

${ }^{13}$ Financial sector size is demeaned to allow for easier interpretation of the interaction terms.
} 
Table 6 In Model (1), we identify whether banks operating in Europe drive our findings. In Model (2), we identify whether foreign banks from neighboring countries might have similar investment patterns as the domestic banks in the host country. Model (3), we identify whether countries acting as financial centers influence our results. In Model (4), the observations are weighted by the inverse of the number of observations of each country. All models are estimated using the two-step system GMM. Windmeijer (2005) corrected standard errors are in the parentheses. AR1 and AR2 are the $p$-values of the tests for first- and second-order autocorrelation, respectively. Hansen is the p-value of the Hansen test of over-identifying restrictions

\begin{tabular}{|c|c|c|c|c|}
\hline & $\begin{array}{l}\text { European } \\
\text { Countries }\end{array}$ & $\begin{array}{l}\text { Contiguous } \\
\text { Countries }\end{array}$ & $\begin{array}{l}\text { Financial Sector } \\
\text { Size }\end{array}$ & $\begin{array}{l}\text { Weighted } \\
\text { Regression }\end{array}$ \\
\hline & (1) & $(2)$ & (3) & (4) \\
\hline \multirow[t]{2}{*}{ Domestic Sovereign Debt $_{t-1}$} & $0.719 * * *$ & $0.708 * * *$ & $0.707 * * *$ & $0.712 * * *$ \\
\hline & $(0.066)$ & $(0.055)$ & $(0.052)$ & $(0.071)$ \\
\hline \multirow[t]{2}{*}{ Domestic bank } & $-0.024 *$ & $-0.022 *$ & $-0.023 *$ & $-0.020^{*}$ \\
\hline & $(0.012)$ & $(0.013)$ & $(0.012)$ & $(0.011)$ \\
\hline Domestic bank $*$ EU & $\begin{array}{l}0.037 \\
(0.028)\end{array}$ & & & \\
\hline $\begin{array}{l}\text { Domestic bank } * \text { Financial } \\
\quad \text { sector size }\end{array}$ & & & $\begin{array}{l}-0.0002 * * \\
(0.0001)\end{array}$ & \\
\hline \multirow[t]{2}{*}{ Foreign Bank } & $-0.039 * *$ & $-0.040^{* *}$ & $-0.033^{* *}$ & $-0.035^{* *}$ \\
\hline & $(0.016)$ & $(0.018)$ & $(0.014)$ & $(0.016)$ \\
\hline Foreign bank $*$ EU & $\begin{array}{l}0.042 \\
(0.031)\end{array}$ & & & \\
\hline Foreign bank $*$ Contiguous & & $\begin{array}{l}-0.233 \\
(0.217)\end{array}$ & & \\
\hline $\begin{array}{l}\text { Foreign bank } * \text { Financial sector } \\
\text { size }\end{array}$ & & & $\begin{array}{l}-0.0001 \\
(0.0001)\end{array}$ & \\
\hline \multirow[t]{2}{*}{ EU } & -0.031 & 0.005 & -0.0006 & 0.007 \\
\hline & $(0.020)$ & $(0.004)$ & $(0.004)$ & $(0.004)$ \\
\hline \multirow[t]{2}{*}{ Contiguous } & & 0.250 & & \\
\hline & & $(0.215)$ & & \\
\hline \multirow[t]{2}{*}{ Financial sector size } & & & 0.00006 & \\
\hline & & & $(0.00009)$ & \\
\hline Control variables & YES & YES & YES & YES \\
\hline Year fixed effects & YES & YES & YES & YES \\
\hline Number of Observations & 1208 & 1208 & 1208 & 1208 \\
\hline Number of Banks & 293 & 293 & 293 & 293 \\
\hline AR1 & 0.000 & 0.000 & 0.000 & 0.000 \\
\hline AR2 & 0.797 & 0.441 & 0.655 & 0.469 \\
\hline Hansen & 0.958 & 0.977 & 0.995 & 0.998 \\
\hline
\end{tabular}

$*, * *$, and $* * *$ denote significance at the $10 \%, 5 \%$, and $1 \%$ levels, respectively

Table 7, indicate that our inferences are not dependent on outliers. In column 2 of Table 7, we address the possibility that our results could be influenced by the way the dependent variable is normalized. To ensure that this is not the case, we reestimate our canonical model using the ratio of domestic sovereign debt to total other earnings assets, instead of the ratio of domestic sovereign debt to total assets. Although the sample of banks with other earnings assets is slightly smaller, our main results on ownership type are unaffected.

Finally, we use two alternative estimation approaches, namely the Tobit model (Tobin 1958) and the factional logit model (Papke and Wooldridge 1996), to assess the robustness of our inferences towards our estimation method. The results from these two estimators are reported in the last two columns of Table 7, respectively. The key findings are corroborated, as we continue to find that foreign-owned banks hold less domestic sovereign bonds than either domestic privately owned banks or government-owned institutions. 
Table 7 In Model (1), we winsorize the dependent variable at the 1st and 99th percentiles of its empirical distribution. In Model (2), we estimate our canonical model using the ratio of domestic sovereign debt to total other earnings assets to address the possibility that our results are influenced by the way the dependent variable is normalized. Both models are estimated using the two-step system GMM. Windmeijer (2005) corrected standard errors are in the parentheses. In Models (3) and (4), we assess the robustness of our inferences with respect to using alternative estimators. Specifically, in Model (3) we estimate our canonical model using the Tobit (Tobin, 1958) estimator, whereas in Model (4) we use the fractional logit model (Papke and Wooldridge, 1996). AR1 and AR2 are the p-values of the tests for first- and second-order autocorrelation, respectively. Hansen is the p value of the Hansen test of over-identifying restrictions

\begin{tabular}{|c|c|c|c|c|}
\hline & $\begin{array}{l}\text { Winsorised Dependent } \\
\text { Variable }\end{array}$ & $\begin{array}{l}\text { Alternative Dependent } \\
\text { Variable }\end{array}$ & $\begin{array}{l}\text { Tobit } \\
\text { Model }\end{array}$ & $\begin{array}{l}\text { Fractional } \\
\text { model }\end{array}$ \\
\hline & (1) & (2) & (3) & (4) \\
\hline \multirow{2}{*}{$\begin{array}{l}\text { Domestic Sovereign } \\
\text { Debt } t_{t-1}\end{array}$} & $0.765 * * *$ & $0.372 * * *$ & & \\
\hline & $(0.045)$ & $(0.073)$ & & \\
\hline \multirow[t]{2}{*}{ Domestic bank } & $-0.014 *$ & $-0.100 * *$ & $-0.040 * * *$ & $-0.305 * * *$ \\
\hline & $(008)$ & $(0.048)$ & $(0.007)$ & $(.058)$ \\
\hline \multirow[t]{2}{*}{ Foreign Bank } & $-0.028 * *$ & $-0.129 * *$ & $-0.054 * * *$ & $-0.327 * * *$ \\
\hline & $(0.012)$ & $(0.054)$ & $(0.008)$ & $(0.081)$ \\
\hline \multirow[t]{2}{*}{ Size } & $-0.003 * *$ & $-0.037 * * *$ & $-0.012 * * *$ & $-0.102 * * *$ \\
\hline & $(0.001)$ & $(0.006)$ & $(0.001)$ & $(0.013)$ \\
\hline \multirow[t]{2}{*}{$\mathrm{E} / \mathrm{TA}$} & -0.047 & -0.280 & $-0.106^{* * *}$ & $-0.778 * *$ \\
\hline & $(0.044)$ & $(0.162)$ & $(0.036)$ & $(0.301)$ \\
\hline \multirow[t]{2}{*}{ Loans/Assets } & -0.020 & 0.005 & $-0.156^{* * * *}$ & $-1.505 * * *$ \\
\hline & $(0.022)$ & $(0.067)$ & $(0.014)$ & $(0.135)$ \\
\hline \multirow[t]{2}{*}{ Sovereign debt yield } & $0.011 * * *$ & $0.072 * * *$ & $0.033 * * *$ & $0.428 * * *$ \\
\hline & $(0.002)$ & $(0.014)$ & $(0.004)$ & $(0.055)$ \\
\hline \multirow[t]{2}{*}{$\left(\right.$ Sovereign debt yield) ${ }^{2}$} & $-0.0005^{* *}$ & $-0.003 * * *$ & $-0.001 * * *$ & $-0.022 * * *$ \\
\hline & $(0.0002)$ & $(0.0009)$ & $(0.0003)$ & $(0.004)$ \\
\hline \multirow[t]{2}{*}{ Debt/GDP } & $0.0003 * * *$ & $0.002 * * *$ & $0.001 * * *$ & $0.013 * * *$ \\
\hline & $(.00007)$ & $(0.0004)$ & $(0.0001)$ & $(0.0008)$ \\
\hline \multirow[t]{2}{*}{ GDP growth } & 0.0006 & $0.010 * * *$ & $0.007 * * *$ & $0.069 * * *$ \\
\hline & $(0.0007)$ & $(0.003)$ & $(0.001)$ & $(0.012)$ \\
\hline \multirow{2}{*}{ Z-score } & 0.0003 & 0.001 & $0.0008^{* * *}$ & $0.009 * * *$ \\
\hline & $(0.0003)$ & $(0.001)$ & $(0.0002)$ & $(0.002)$ \\
\hline \multirow[t]{2}{*}{ Market concentration } & 0.00007 & 0.00007 & $-0.0004 * * *$ & -0.0009 \\
\hline & $(0.0001)$ & $(0.0005)$ & $(0.001)$ & $(0.001)$ \\
\hline \multirow[t]{2}{*}{ Boone indicator } & $0.036^{*}$ & $0.223 *$ & $0.14 * * *$ & $2.330 * * *$ \\
\hline & $(0.021)$ & $(0.117)$ & $(0.035)$ & $(0.443)$ \\
\hline \multirow[t]{2}{*}{$\mathrm{EU}$} & 0.006 & 0.039 & -0.002 & -0.050 \\
\hline & $(0.008)$ & $(0.029)$ & $(0.006)$ & $(0.075)$ \\
\hline Year fixed effects & YES & YES & YES & YES \\
\hline Number of Observations & 1208 & 1096 & 1208 & 1208 \\
\hline Number of Banks & 293 & 285 & 293 & 293 \\
\hline AR1 & 0.000 & 0.000 & & \\
\hline AR2 & 0.815 & 0.781 & & \\
\hline Hansen & 0.918 & 0.649 & & \\
\hline
\end{tabular}

$*$, **, and $* * *$ denote significance at the $10 \%, 5 \%$, and $1 \%$ levels, respectively

In sum, we consistently observe a negative effect of foreign and domestic private ownership on the size of banks' sovereign bond portfolios relative to government-owned institutions. These findings lend support to our key hypothesis that the proportion of banks' holdings of domestic sovereign bonds can be explained by their ownership structure, the quality of governance, and the development of the banking system in the countries in which they operate. 


\section{Concluding Remarks}

In this paper, we examine the determinants of domestic sovereign bond holdings by using a panel data of 295 banks in 35 countries between 2002 and 2013. We hypothesize that decisions on the allocations of domestic sovereign bonds are affected by the ownership structure of the banks as well as institutional characteristics. In the empirical analysis we find that government-owned banks hold more domestic sovereign debt. The effect of the ownership structure is particularly important when the domestic sovereign bond yields are high. Banks whose ultimate owner is a foreign entity are less prone to home bias in their bond holdings, and banks that operate in countries with better institutional environments hold fewer domestic sovereign bonds.

In terms of its contribution to the literature, unlike prior studies, this paper examines the home bias hypothesis in holding sovereign debt in an international context and beyond the Eurozone area. We find that the home bias in holding sovereign debt is an international phenomenon. Indeed, our tests show that banks operating in the EU do not have levels of home bias that are different from the banks that operate in non-EU countries. The impact of regulation on home bias and on the sovereign-bank feedback loop is an important topic that is not fully explored in our analysis. The empirical results in our particular setting show that regulatory standards do not seem to significantly impact home bias. However, our empirical analysis does not test for the indirect effects caused by regulatory standards, such as those described by Kirschenmann et al. (2017).

Overall, our empirical results show that moral suasion is an important determinant of banks' home bias in holding sovereign bonds. We interpret our results as evidence that governments can sway banks, especially domestic and government-owned ones, to purchase domestic sovereign bonds, even if these purchases are not optimal from an asset allocation perspective. Europe has taken important steps toward moderating the negative feedback loop between bank debt and sovereign debt with the introduction of the banking union and the establishment of the Single Supervisory Mechanism and the Single Resolution Mechanism. The supervision of systemic banks at the European level and the monitoring of their board members will most likely weaken governments' ability to influence banks' investment decisions with respect to bond purchases and credit allocation in general.

Acknowledgments We would like to thank participants at the Conference on 'Banking, Finance, Money and Institutions: The Post Crisis Era' at the University of Surrey, 2013, the 2014 World Finance Conference in Venice, the IFABS 2016 Barcelona Conference, the 2016 FMA Annual Meeting and the 2018 FEBS Conference for useful comments and suggestions on an earlier draft. Any remaining errors are our own responsibility. The authors also acknowledge financial support from the British Academy/SAMS Small Research Grant under research project number SG140376.

Open Access This article is distributed under the terms of the Creative Commons Attribution 4.0 International License (http://creativecommons.org/licenses/by/4.0/), which permits unrestricted use, distribution, and reproduction in any medium, provided you give appropriate credit to the original author(s) and the source, provide a link to the Creative Commons license, and indicate if changes were made.

\section{References}

Acharya VV, Drechsler I, Schnabl P (2015) A Pyrrhic victory? Bank bailouts and sovereign credit risk. J Financ 69:2689-2739

Acharya VV, Steffen S (2015) The "greatest" carry trade ever? Understanding Eurozone bank risks. J Financ Econ 115(2):215-236 
Asonuma S, Bakhache S, Hesse H (2015) Is banks' home bias good or bad for public debt sustainability? IMF Working Paper 15/44

Baltagi BH (2008) Econometric analysis of panel data, 4th edn. John Wiley and Sons, Chichester

Becker B, Ivashina V (2017) Financial repression in the European sovereign debt crisis. Rev Financ 22(1):83115

Berger A, Clarke GRG, Cull R, Klapper L, Udell GF (2005) Corporate governance and bank performance: A joint analysis of the static, selection, and dynamic effects of domestic, foreign, and state ownership. J Bank Financ 29:2179-2221

Blundell R, Bond S (1998) Initial conditions and moment restrictions in dynamic panel data models. J Econ 87: $115-143$

Bond SR (2002) Dynamic panel data models: A guide to micro data methods and practice. Port Econ J 1:141162

Brissimis SN, Delis M, Papanikolaou NI (2008) Exploring the nexus between banking sector reform and performance: Evidence from newly acceded EU countries. J Bank Financ 32(12):2674-2683

Broner F, Erce A, Martin A, Ventura J (2014) Sovereign debt markets in turbulent times: Creditor discrimination and crowding-out effects. J Monet Econ 61:114-142

Chronopoulos DK, Girardone C, Nankervis JC (2013) How do stock markets in the US and Europe price efficiency gains from bank M\&As? J Financ Serv Res 43(3):243-263

Čihák MA, Demirgüç-Kunt A, Feyen E, Levine R (2012) Benchmarking financial systems around the world. World Bank Policy Research Working Paper 6175

Claessens S, van Horen N (2015) The impact of the global financial crisis on banking globalization. IMF Econ Rev 63:868-918

Coval JD, Moskowitz TJ (1999) Home bias at home: Local equity preference in domestic portfolios. J Financ 54: 2045-2073

Crosignani M (2015) Why are banks not recapitalized during crises? ONB Working Paper 203

De Marco F, Macchiavelli M (2016) The political origin of home bias: The case of Europe. Finance and Economics Discussion Series 2016-060 Board of Governors of the Federal Reserve System

Drechsler I, Drechsel T, Marques-Ibanez D, Schnabl P (2016) Who borrows from the lender of last resort? J Financ 71:1933-1974

Gelos RG, Wie SJ (2005) Transparency and international portfolio holdings. J Financ 60(6):2987-3020

Hasan I, Wang H, Zhou M (2009) Do better institutions improve bank efficiency? Evidence from a transitional economy. Manag Financ 35(2):107-127

Horváth BL, Huizinga H, Ioannidou V (2015) Determinants and valuation effects of the home bias in European banks' sovereign debt portfolios. CEPR Discussion Paper 10661

Kaufmann D, Kraay A, Mastruzzi M (2009) Governance matters VIII: Aggregate and individual governance indicators, 1996-2008. World Bank Policy Research Working Paper No. 4978

Kirschenmann K, Korte J, Steffen S (2017) The zero risk fallacy? Banks' sovereign exposure and sovereign risk spillovers. ZEW Discussion Paper No 17-069

Lensink R, Meesters A, Naaborg I (2008) Bank efficiency and foreign ownership: Do good institutions matter? J Bank Financ 32:834-844

Nickell SJ (1981) Biases in dynamic models with fixed effects. Econometrica 49:1417-1426

Ongena S, Popov AA, van Horen N (2018) The invisible hand of the government: 'Moral suasion' during the European sovereign debt crisis. Amer Econ J: Macroeco, forthcoming

Papke LE, Wooldridge JF (1996) Econometric methods for fractional response variables with an application to 401(k) plan participation rates. J Appl Econ 11:619-632

Reinhart MC, Sbrancia MB (2011) The liquidation of government debt. NBER Working Paper 16893

Romans J (1966) Moral suasion as an instrument of economic policy. Am Econ Rev 56:1220-1226

Shleifer A, Vishny R (1997) A survey of corporate governance. J Financ 52:737-783

Tobin J (1958) Estimation of relationships for limited dependent variables. Econometrica 26:24-36

Uhlig H (2013) Sovereign default risk and banks in a monetary union. NBER Working Paper 19343

van Nieuwerburgh S, Veldkamp L (2009) Information immobility and the home bias puzzle. J Financ 64:11871215

Windmeijer F (2005) A finite sample correction for the variance of linear efficient two-step GMM estimators. J Econ 126:25-51

Publisher's Note Springer Nature remains neutral with regard to jurisdictional claims in published maps and institutional affiliations. 